\title{
Front Matter: Volume 8203
}

, "Front Matter: Volume 8203," Proc. SPIE 8203, Remote Sensing of the Environment: The 17th China Conference on Remote Sensing, 820301 (14 September 2011); doi: 10.1117/12.911890 SPIE. Event: Seventeenth China Symposium on Remote Sensing, 2010, Hangzhou, 


\title{
PROCEEDINGS OF SPIE
}

\section{Remote Sensing of the Environment: The 17th China Conference on Remote Sensing}

\author{
Qingxi Tong \\ Xingfa Gu \\ Boqin Zhu \\ Editors
}

\section{7-31 August 2010 \\ Hangzhou, China}

Organized by

Chinese National Committee for Remote Sensing

Hosted by

Association on Environment Remote Sensing of China • Hangzhou Normal University

The Institute of Remote Sensing Applications, Chinese Academy of Sciences

International Sponsors

SPIE • International Society for Digital Earth • UNDESA GAID e-SDDC • Asian Association on Remote Sensing IEEE Beijing Section

\section{Sponsored by}

National Remote Sensing Center of China • Association on Environment Remote Sensing Of China • Committee of Remote Sensing For Geology, The Geological Society of China • Committee on Ocean Remote Sensing, Chinese Society of Oceanography • Committee on Satellite Meteorology and Space Weather, China Meteorological Society • Committee on Space Remote Sensing, Chinese Society of Space Research • Committee on Photogrammetry and Remote Sensing, Chinese Society of Geodesy • Photogrammetry and Cartography Technical Committee on Avionics, Chinese Society of Aeronautics and Astronautics • Committee on Space Remote Sensing, Chinese Society of Astronautics • Committee on Telemetry, Remote Sensing and Control, Chinese Association of Automation • Committee on Software Industry, China Association for Geographic Information System • Committee on Remote Sensing, Chinese Hydraulic Engineering Society • Affiliated Society of Land Information and Remote Sensing, Chinese Land Society • Chinese National Committee, International Society for Digital Earth United Remote Sensing Application Research Center of Chinese Universities • Committee on Environmental Information System and Remote Sensing, Chinese Society for Environmental Sciences

Local Organizers

Hangzhou Normal University • Zhejiang Science and Technology Association • Zhejiang Development and Reform Commission Zhejiang Economic and Information Technology Commission • Zhejiang Provincial Department of Education • Zhejiang Science and Technology Department • Zhejiang Provincial Department of Land and Resources $\bullet$ Zhejiang Bureau of Surveying and Mapping

Special Support

Tianjin Branch of Remote Sensing Information Technology Company, Ltd. • Strategic Alliances of Industrial and Technical Innovation for Remote Sensing Data Processing and Analysis • Strategic Alliances of Industrial and Technical Innovation for Small Satellite Remote Sensing Systems

Published by

SPIE

Volume 8203

Proceedings of SPIE, 0277-786X, v. 8203

SPIE is an international society advancing an interdisciplinary approach to the science and application of light.

Remote Sensing of the Environment: The 17th China Conference on Remote Sensing, edited by Qingxi Tong, Xingfa Gu, Boqin Zhu, Proc. of SPIE Vol. 8203, 820301

(c) 2011 SPIE $\cdot$ CCC code: $0277-786 X / 11 / \$ 18 \cdot$ doi: $10.1117 / 12.911890$ 
The papers included in this volume were part of the technical conference cited on the cover and title page. Papers were selected and subject to review by the editors and conference program committee. Some conference presentations may not be available for publication. The papers published in these proceedings reflect the work and thoughts of the authors and are published herein as submitted. The publisher is not responsible for the validity of the information or for any outcomes resulting from reliance thereon.

Please use the following format to cite material from this book:

Author(s), "Title of Paper," in Remote Sensing of the Environment: The 17th China Conference on Remote Sensing, edited by Qingxi Tong, Xingfa Gu, Boqin Zhu, Proceedings of SPIE Vol. 8203 (SPIE, Bellingham, WA, 2011) Article CID Number.

ISSN 0277-786X

ISBN 9780819488442

Published by

SPIE

P.O. Box 10, Bellingham, Washington 98227-0010 USA

Telephone +1 3606763290 (Pacific Time) · Fax +1 3606471445

SPIE.org

Copyright (C) 2011, Society of Photo-Optical Instrumentation Engineers

Copying of material in this book for internal or personal use, or for the internal or personal use of specific clients, beyond the fair use provisions granted by the U.S. Copyright Law is authorized by SPIE subject to payment of copying fees. The Transactional Reporting Service base fee for this volume is $\$ 18.00$ per article (or portion thereof), which should be paid directly to the Copyright Clearance Center (CCC), 222 Rosewood Drive, Danvers, MA 01923. Payment may also be made electronically through CCC Online at copyright.com. Other copying for republication, resale, advertising or promotion, or any form of systematic or multiple reproduction of any material in this book is prohibited except with permission in writing from the publisher. The CCC fee code is 0277-786X/11/ \$18.00.

Printed in the United States of America.

Publication of record for individual papers is online in the SPIE Digital Library.

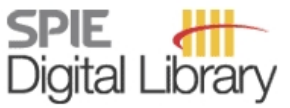

SPIEDigitalLibrary.org

Paper Numbering: Proceedings of SPIE follow an e-First publication model, with papers published first online and then in print and on CD-ROM. Papers are published as they are submitted and meet publication criteria. A unique, consistent, permanent citation identifier (CID) number is assigned to each article at the time of the first publication. Utilization of CIDs allows articles to be fully citable as soon as they are published online, and connects the same identifier to all online, print, and electronic versions of the publication. SPIE uses a six-digit CID article numbering system in which:

- The first four digits correspond to the SPIE volume number.

- The last two digits indicate publication order within the volume using a Base 36 numbering system employing both numerals and letters. These two-number sets start with $00,01,02,03,04$, $05,06,07,08,09,0 A, 0 B \ldots 0 Z$, followed by 10-1Z, 20-2Z, etc.

The CID number appears on each page of the manuscript. The complete citation is used on the first page, and an abbreviated version on subsequent pages. Numbers in the index correspond to the last two digits of the six-digit CID number. 


\section{Contents}

ix Conference Committees
xiii Introduction

\section{THEORY AND TECHNOLOGY}

820302 Field investigation system and its application in forest pest survey [8203-02]

Y. Qiao, Y. Chang, Y. Zhang, W. Li, J. Jian, Institute of Remote Sensing Applications (China)

820303 A method of relative radiometric correction for linear push-broom CCD Image without calibration device onboard [8203-03]

M. Yan, Beijing Landview Mapping Information Technology Co., Ltd. (China); Z. Wang, Beijing Landview Mapping Information Technology Co., Ltd. (China) and Twenty First Century Aerospace Technology Co., Ltd. (China); S. He, F. WU, B. Yu, Beijing Landview Mapping Information Technology Co., Ltd. (China)

820304 Lunar and Mars orbital stereo image mapping [8203-04]

M. Peng, Z. Yue, Y. Liu, K. Di, Institute of Remote Sensing Applications (China)

820305 Rover localization from long stereo image sequences using visual odometry based on bundle adjustment [8203-05]

W. Wan, Z. Liu, K. Di, Institute of Remote Sensing Applications (China)

820306 Removing the stripe noise in HJ-1A HSI images [8203-06]

H. Gao, State Key Lab. of Remote Sensing Science (China), Graduate Univ. of Chinese Academy of Sciences (China), and The Ctr. for National Spaceborne Demonstration (China); X. Gu, T. YU, X. Li, State Key Lab. of Remote Sensing Science (China) and The Ctr. for National Spaceborne Demonstration (China); J. Zhi, State Key Lab. of Remote Sensing Science (China), The Ctr. for National Spaceborne Demonstration (China), and Henan Univ. (China); Y. Xie, X. Ma, State Key Lab. of Remote Sensing Science (China), The Ctr. for National Spaceborne Demonstration (China), and Henan Polytechnic Univ. (China)

820307 The analysis on parameters of the payload on hyperspectral satellite [8203-07] D. Wang, China Aero Geophysical Survey \& Remote Sensing Ctr. for Land and Resources (China); F. Hou, Capital Normal Univ. (China); Z. Li, China Geological Survey (China); F. Dang, R. Yang, Z. Xiao, China Aero Geophysical Survey \& Remote Sensing Ctr. for Land and Resources (China)

820308 Joint rectification of image series classification results based on trajectory analysis [8203-08] D. Wang, Tianjin Institute of Urban Construction (China) and Institute of Remote Sensing Applications (China); J. Gong, Institute of Remote Sensing Applications (China); L. Zhang, Tianjin Institute of Urban Construction (China) and Institute of Remote Sensing Applications (China) 
820309 The application of precise point positioning in the IMU/GPS-supported photogrammetry [8203-09]

M. Liao, Y. Li, L. Zhang, X. Chen, China TopRS Technology Co., Ltd. (China)

8203 OA Modeling the bidirectional reflectance distribution function (BRDF) of water based on Monte Carlo simulation [8203-10]

Z. Ling, Hangzhou Normal Univ. (China); B. Zhou, Hangzhou Normal Univ. (China) and Zhejiang Univ. (China); J. Jiang, Hangzhou Normal Univ. (China); W. Dou, F. Zhou, Zhejiang Univ. (China)

8203 OB Signal to noise ratio simulation of lake water color monitoring oriented satellite remote sensing system [8203-11]

J. Tian, B. Peng, J. Wang, X. Li, Nanjing Univ. (China)

8203 OC Effect of instrument tilts on in-water radiometric profile measurements and data analysis [8203-12]

B. Tao, State Oceanic Administration (China), Shanghai Institute of Technical Physics (China), and Graduate School of Chinese Academy of Sciences (China); Z. Mao, B. Yan, State Oceanic Administration (China); B. Jin, PLA Univ. of Science and Technology (China)

8203 OD Methods to locate and eliminate the solar specular reflection point in the meteorological satellite images [8203-14]

W. Li, Beijing Aviational Institute (China); B. Huang, Beijing Aviational Institute (China) and Physical Institute Beijing Univ. (China); J. Bai, X. Wang, Beijing Aviational Institute (China)

8203 OE Status monitoring and exception handling mechanism for geospatial information services [8203-13]

D. Zhang, B. Xie, Hangzhou Normal Univ. (China); Y. Ma, Zhejiang Univ. (China)

\section{ALGORITHM AND MODEL}

8203 OF Intercalibration of SVISSR/FY-2 thermal infrared channels with AIRS/Aqua channels [8203-15] G. Jiang, Y. Jin, Fudan Univ. (China)

8203 OG A 3-dimensional polynomial model for geometric corrections of airborne SAR images [8203-16]

J. Song, Ctr. for Earth Observation and Digital Earth (China) and Graduate Univ. of the Chinese Academy of Sciences (China); J. Liao, Ctr. for Earth Observation and Digital Earth (China)

$8203 \mathrm{OH} \quad$ Orthoimage seamline searching based on minimizing local maximum algorithm [8203-17] C. Zhong, Remote Sensing College of Wuhan Univ. (China); Y. Yang, Wuda Geoinformatics Co., Ltd. (China)

8203 0l Delay/Doppler radar altimeter simulation echoes from different sea states [8203-18] L. Shi, Ctr. for Space Science and Applied Research (China) and Graduate School of the Chinese Academy of Science (China); H. Liu, K. XU, S. Yang, X. XU, Ctr. for Space Science and Applied Research (China) 
8203 OJ Rice identification using TerraSAR-X data [8203-19]

L. Guo, Z. Pei, S. Zhang, Q. Wang, Ministry of Agriculture of China (China); H. McNairn,

J. Shang, X. Jiao, Agriculture and Agri-Food Canada (Canada)

8203 OK Comparison of Landsat-7 ETM+ and ASTER NDVI measurements [8203-20]

$\mathrm{H}$. Xu, T. Zhang, Fuzhou Univ. (China)

8203 OL Aerosol optical depth retrieval over land using FY-3A data and its application in dust monitoring [8203-21]

L. Mei, State Key Lab. of Remote Sensing Science (China) and Graduate Univ. of the Chinese Academy of Sciences (China); Y. Xue, State Key Lab. of Remote Sensing Science (China) and London Metropolitan Univ. (United Kingdom); J. Guang, State Key Lab. of Remote Sensing Science (China); Y. Li, Y. Wang, H. XU, X. He, State Key Lab. of Remote Sensing Science (China) and Graduate Univ. of the Chinese Academy of Sciences (China); S. Jiang, X. Jiao, Shandong Univ. of Science and Technology (China); Z. Chen, Ctr. for Earth Observation and Digital Earth (China) and Graduate Univ. of the Chinese Academy of Sciences (China); J. Ai, Guangdong Electronics Industry Institute (China)

8203 OM The inversion of average vegetation height using ICESat GLAS and MODIS data: a case study of three provinces in Northeastern China [8203-22]

F. Cheng, Yunnan Normal Univ. (China) and Ctr. for Earth Observation and Digital Earth (China); C. Wang, Ctr. for Earth Observation and Digital Earth (China); X. Jiang, Academy of Opto-Electronics (China)

8203 ON Space-borne hyperspectral remote sensing imagery noise eliminating based on CFFT self-adapted by optimal SNR [8203-23]

Q. Liu, Q. Lin, L. Wang, Q. Wang, Ctr. for Earth Observation and Digital Earth (China) and Key Lab. of Digital Earth (China); F. Miao, STATE Grid AC Engineering Construction Co. (China)

\section{INFORMATION EXTRACTION}

820300 Monitor the microwave thermal emission anomaly around the Yushu earthquake fault zone by using AMSR-E data [8203-24]

H. Chen, Y. Jin, Fudan Univ. (China)

8203 OP Mapping land cover of the Yellow River source using multi-temporal Landsat images [8203-25]

Y. Hu, Ctr. for Earth Observation and Digital Earth (China) and Xi'an Univ. of Science \& Technology (China); L. Liu, L. Liu, Q. Jiao, Ctr. for Earth Observation and Digital Earth (China); J. Jia, Xi'an Univ. of Science \& Technology (China)

$82030 Q \quad$ Spectral matching based on hidden Markov model [8203-26]

J. Fu, N. Shu, X. Kong, Wuhan Univ. (China)

8203 OR Synthesis of multi-scale segmentation results based on land cover categories [8203-27] L. Yi, Z. Wu, Wuhan Univ. (China); G. Zhang, Academy of Opto-Electronics (China); Y. Zhang, Wuhan Univ. (China) 
8203 OS The extraction of mangrove within intertidal zone based on multi-temporal HJ CCD images [8203-28]

S. Li, Q. Tian, Nanjing Univ. (China); T. Yu, X. Gu, Institute of Remote Sensing Applications (China)

8203 OT Wetland extraction of Yancheng coastal area based on ALOS data [8203-29]

Y. Weng, Southeast Univ. (China) and State Key Lab. of Remote Sensing Science (China);

$X$. Fan, J. Tao, Southeast Univ. (China)

8203 OU The application and research of anomaly extraction process by remote sensing in the vegetation-covered area: an example in Chengmenshan of JiuJiang district [8203-30] Y. Chen, Jiangxi Insititute of Geology Survey (China); P. T. Zhang, Exploration and Development of Geology and Mineral Resources Ctr. of Jiangxi Province (China); P. Xu, Jiangxi Insititute of Geology Survey (China)

8203 OV Object and rule based approach for classification of high spatial resolution data over urban areas [8203-31]

L. Ni, Ctr. for Earth Observation and Digital Earth (China)

\section{RESOURCES, ENVIRONMENT, AND DISASTER}

8203 OW Land-cover change of the wuda coal fire area [8203-32]

C. Zhang, Y. Guan, S. Guo, Institute of Remote Sensing Application (China); J. Li, The High Technology Research and Development Ctr. (China) and National Remote Sensing Ctr. of China (China); J. Wu, Beijing Normal Univ. (China); Y. Jia, Shenhua Wuhai Energy Co. Ltd. (China); D. Cai, Institute of Remote Sensing Application (China); H. Duan, X. Zhang, Shenhua (Beijing) Remote Sensing\&GEO-Engineering Co. Ltd. (China); T. Zhao, Shenhua Wuhai Energy Co. Ltd. (China); X. An, L. Kang, Institute of Remote Sensing Application (China)

$82030 X$ The influence of urban reconstruction in urban heat island effect: Cangxia area of Fuzhou City, China [8203-33] F. Tang, H. Xu, Fuzhou Univ. (China)

8203 OY Changes of forest in northeast China over the past 25 years: an analysis based on remote sensing technique [8203-34]

L. Shi, Peking Univ. (China)

$82030 Z$ Analysis of acid rain effects on vegetation in eco-regions in China based on AVHRR/NDVI [8203-35]

J. Jin, Nanjing Univ. (China); H. Jiang, Nanjing Univ. (China) and Zhejiang Agriculture and Forestry Univ. (China); X. Zhang, Nanjing Univ. (China); X. XU, China Meteorological Administration (China)

820310 Damage assessment of Haiti earthquake emergency using high resolution remote sensing imagery [8203-36]

L. Wang, A. Dou, X. Wang, Y. Dong, X. Ding, Institute of Earthquake Science (China); Z. Li, Liaoning Seismological Bureau (China); X. Yuan, Y. Qiu, Institute of Earthquake Science (China) 
820311 Technology and application of emergency spatial data management [8203-37]

H. Du, Capital Normal Univ. (China), The Ctr. of Surveying and Mapping (China), Beijing Key Lab. of Resources Environment and GIS (China), and 3D Information Acquisition and Application Key Lab. of the Education Ministry (China); H. Gong, Capital Normal Univ. (China), Beijing Key Lab. of Resources Environment and GIS (China), and 3D Information Acquisition and Application Key Lab. of the Education Ministry (China); Z. Jiang, J. Jia, Z. Quan, The Ctr. of Surveying and Mapping (China)

820312 Drought monitoring in Yunnan province with AMSR-E-based data [8203-38]

S. Wang, R. Zhong, Q. Li, M. Qin, Capital Normal Univ. (China)

820313 Analysis of the ancient river system in Loulan period in Lop Nur region [8203-39] J. Zhu, P. Jia, Y. Nie, Institute of Remote Sensing Applications (China)

820314 Spatial scale of chlorophyll-a concentration in Lake Taihu by using remote sensing images [8203-40]

Y. Bao, Q. Tian, Nanjing Univ. (China)

820315 The investigation of special information distilling method of land use in karst area based on CBERS-02B and analysis on application: a case study of Duyun, Guizhou [8203-41] J. Hu, M. Luo, Y. An, Guizhou Normal Univ. (China)

820316 Typical disaster damage target extraction method based on object oriented classification [8203-42]

G. Wang, Institute of Remote Sensing Applications (China); F. Wang, National Astronomical Observatories (China); J. Chen, Institute of Remote Sensing Applications (China); S. Chen, National Disaster Reduction Ctr. of China (China)

820317 Design of highway landslide warning and emergency response systems based on UAV [8203-43]

Y. Huang, S. Yi, Z. Li, S. Shao, X. Qin, Research Institute of Highway (China) and Environmental Protection Ctr. (China)

820318 Wetland information extraction of remote sensing imagery based on Markov random field theory [8203-44]

D. Zhang, Hangzhou Normal Univ. (China); Y. Wu, Zhejiang Univ. (China)

820319 Applications of RADARSAT-2 in remote sensing dynamic monitoring of land use [8203-45] B. Cheng, Ctr. for Earth Observation and Digital Earth (China); Y. Chai, China Land Surveying and Planning (China); L. Kou, G. He, Ctr. for Earth Observation and Digital Earth (China); L. Wen, Y. Zhan, China Land Surveying and Planning (China)

INTEGRATED AND OTHERS

$82031 \mathrm{~A}$ Assessment on aerosol direct radiative forcing over China land areas based on satellite data [8203-46]

L. Chen, China Meteorological Administration (China); G. Shi, B. Wang, Institute of Atmospheric Physics (China); P. Zhang, China Meteorological Administration (China) 
8203 1B Risk evaluation of available phosphorus loss in agricultural land based on remote sensing and GIS [8203-47]

$X$. Ding, Hangzhou Normal Univ. (China); B. Zhou, Hangzhou Normal Univ. (China) and Zhejiang Univ. (China); J. Xu, T. Liu, B. Xie, Hangzhou Normal Univ. (China)

$82031 \mathrm{C}$ Association of influenza virus isolation with environmental factors in mainland China based on remote sensing and GIS [8203-48]

Y. Ren, Y. Liu, L. Hu, J. Fan, Institute of Remote Sensing Applications (China); X. Li, Institute of Remote Sensing Applications (China) and Beijing Normal Univ. (China)

8203 ID Optical absorption properties of water components in Xixi wetland of Hangzhou [8203-49] F. Zhou, Zhejiang Univ. (China); B. Zhou, Zhejiang Univ. (China) and Hangzhou Normal Univ. (China); W. Zhu, Hangzhou Normal Univ. (China); W. Dou, Zhejiang Univ. (China); Z. Ling, Hangzhou Normal Univ. (China)

8203 IE Aerosol direct radiative forcing at the top of atmosphere based on satellite remote sensing over China seas: a preliminary study [8203-50]

Z. Hao, D. Pan, F. Gong, State Oceanic Administration (China)

$8203 \mathrm{IF}$ The statistical prediction model for prospecting Nickel-Copper deposit based on aster remote sensing-geochemistry data in JinChuan and its peripheral [8203-51]

S. Chen, China Univ. of Geosciences (China), Guilin Univ. of Technology (China), Key Lab. of Geological Engineering Ctr. of Guangxi Province (China), and Ministry of Education (China); H. Wu, Guilin Univ. of Technology (China), Key Lab. of Geological Engineering Ctr. of Guangxi Province (China), and Ministry of Education (China); J. Chen, China Univ. of Geosciences (China)

8203 IG Application of ATOVS radiance assimilation to numerical simulation of a mesoscale heavy rainfall [8203-52]

H. Bing, Beijing Univ. (China) and Beijing Aviation Meteorology Institute (China); B. Jie, L. Wei, $X$. Wang, Beijing Aviation Meteorology Institute (China)

8203 1H Residential mobility microsimulation models [8203-53]

Y. Wang, L. Wu, Peking Univ. (China)

Author Index 


\title{
Conference Committees
}

\author{
Symposium Committee \\ Chair \\ Qingxi Tong \\ Steering Committee \\ President \\ Guanhua Xu
}

Members

Wei Gao, Xingfa Gu, Huadong Guo, Jingshan Jiang, Deren Li,

Xiaowen Li, Hui Lin, Chuang Liu, Jiyuaan Liu, Jiyuan Liu, Enjie Luan,

Min Wang, Delu Pan, Jiadong Sun, Yulong Tian, Qingxi Tong,

Chao Wang, Qinmin Wang, Zhishi Wang, Yirong Wu, Guanhua Xu, Jianmin $\mathrm{Xu}$, Yongqi Xue, Kai Yang

Organizing Committee

President

Xingfa Gu

Members

Shuying Cai, Yuan Chai, Jun Chen, Kangwen Chen, Xiuwang Chen, Shaochun Cui, Peijun Du, Yida Fan, Huili Gong, Jianya Gong,

Peng Gong, Jianning Guo, Liqiao Guo, Dong Jiang, Wenbiao Jiang,

Xingwei Jiang, Guifei Jing, Jianhua Ju, Jiahong Li, Jiren Li, Shuming Li,

Wei Li, Xiaoming Li, Yan Li, Yanhua Li, Ying Li, Zengyuan Li,

Zhengqiang Li, Zhizhong Li, Mingsen Lin, Zhaojun Liu, Heguang Liu,

Liangming Liu, Renyi Liu, Yongwei Liu, Mingsheng Lu, Zhihua Mao, 
Jinshan Mei, Yiqi Peng, Shizhao Qiao, Qiming Qin, Changqing Song,

Youchuan Wan, Erhe Wang, Guanghua Wang, Jianyu Wang,

Jinnian Wang, Ke Wang, Ping Wang, Qiao Wang, Yupu Wang,

Zhiyong Wang, Hong Wu, Lun Wu, Shuang Wu, Xuebao Wu, Zhen Xu,

Jun Yang, Kun Yang, Rihong Yang, Shengtian Yang, Yide Yang,

Wuyi Yu, Huanyin Yue, Tao Yue, Lan Zeng, Xianfeng Zhang, Bing Zhang,

Dengrong Zhang, Guocheng Zhang, Jiashen Zhang, Jixian Zhang,

Jun Zhang, Wenruo Zhang, Dongzhi Zhao, Jicheng Zhao, Ruiyun Zhao,

Wenbo Zhao, Lizhong Zheng, Chenghu Zhou, Guoqing Zhou, Boqin Zhu,

Weiping Zhu

\author{
Secretary General \\ Boqin Zhu \\ LOC Members \\ Honorary Presidents \\ Delu Pan \\ Zhaoxi Mao \\ President \\ Gaoxiang Ye \\ Vice Presidents \\ Jianguo Chen \\ Fengjun Cui \\ Kangsheng Ding \\ Guoqiang Deng \\ Lu Li \\ Shanzeng Li \\ Shengming Pan
}

Members

Di Rong Dai, Rixiang Gong, Cunhong Hua, Jingfeng Huang,

Yizhong Huang, Renkang Jin, Feng Li, Longyun Li, Jian Liu,Nan Liu, 
Renyi Liu, Zhihua Mao, Minghai Mao, Hongkun Qiu, Jianhua Sun,

Ke Wang, Xiaoyan Wang, Xiaoyu Wang, Junqing Wu, Weijin Xu,

Zhemin Xu, Dengrong Zhang, Changbao Zhou, Dan Zhou, Yimin Zhou, Weiping Zhu

Secretariat

Secretary General

Boqin Zhu

Deputy Secretary Generals

Fei Gao

Jie Wu

Dengrong Zhang

Members

Dongjie Shen, Jiuhe Chen, Weiwei Cheng, Haiqing Huang, Peng Jia,

Yonggui Jiang, Fang Long, Tong Shuai, Guojun Wang, Lei Wang,

Junfeng $X U$, LU Yu, Bin Zhou, Weiping Zhu 
Proc. of SPIE Vol. $8203820301-12$

Downloaded From: https://www.spiedigitallibrary.org/conference-proceedings-of-spie on 26 Apr 2023 Terms of Use: https://www.spiedigitallibrary.org/terms-of-use 


\section{Introduction}

The biennial China Symposium on Remote Sensing was held in the beautiful southern city of Hangzhou, China in August 2010. It was another significant event for academic exchange in China's remote sensing community after the 30th ACRS that was successfully held in Beijing in 2009.

Due to the diversity and complexity of the natural resources and environmental conditions in China, as well as the large size of the national territory including the land and sea, the studies of geosciences in China has required increasing use of remote sensing technology. Through recent technological progresses, the resolution of optical RS has much increased, new hyperspectral and microwave remote sensing have become more developed, and their influence on and contribution to the geosciences research have been more obviously apparent. The synoptic and integral features of the RS technologies and observations have led to a more systematic and comprehensive development of geosciences, which enables us to study and review more thoroughly our Earth, her resources and environment, as well as the changes she is undergoing.

On the other hand, China's economic and social development has entered into the high speed way. The resource-saving and environment-friendly approach of development has also raised more urgent, direct, and precise requirements for RS technologies, including satellites and airborne observation, especially when faced with the most severe challenges of resource, environment, and natural disasters. It is these requirements that provide the enormous impulse for RS development. The tasks in front of the Chinese RS community are hard and with great challenges.

It is also important to mention that in 2010 the curtain has been drawn across the $11^{\text {th }}$ Five-year Plan of China's national economic development and the more significant $12^{\text {th }}$ Five-year Plan for 2011-2015 has already started. Therefore the important themes of this symposium were to look back and summarize the development and progress of RS technologies in China in the recent years, to communicate the experiences in studies, to exhibit the achievements in RS applications, as well as to discuss and anticipate the prospects of the new period. 
Many people engaged in RS science and technology from different areas of the country gathered together to exchange and discuss with one another across the many themes and fields, demonstrating their enormous motivation and enthusiasm. The more than 50 papers collected and selected in the proceedings well represent the achievements of this symposium. They cover quantitative approach on satellite RS and radiometric calibration, RS applications technological achievements represented by information processing and extraction, the development and applications of hyperspectral and microwave RS, the development of high accuracy and stereo mapping technologies that are mainly of stereo imagery multi-level matching methods based on the Moon and the Mars's explorations in China and abroad, disasters information extraction methods oriented at the emergency response to disaster relief areas, UAV monitoring, responding and warning technologies of road slides that are devastating in the mountainous areas, and the achievements in RS applications in the resources and environment fields, including the areas of land, urban, agriculture and vegetations. There are also papers contacting the RS technologies in exploration of geology and minerals, as well as the problems of geo-biochemical effects.

It is because of the abundant fruits of research by the authors of the papers that the contents of the proceedings have expanded and enriched as well as promoted both RS technology and its increasing applications. From one side the published proceedings are reflecting some features of the recent development of China's RS and its applications and it's just like a water drop in the sea of China's RS fields and a paving stone in its road of development. I should express my deep respect to all authors, reviewing experts, and editors of the papers in the proceedings, and to all the staff of China National Committee on Remote Sensing who has contributed to the edition and publication of the proceedings, as well as my gratefulness to SPIE experts who supported this symposium and the proceedings publication. Finally, I would like give my sincere congratulations upon the release of the proceedings!

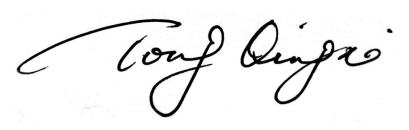

Qingxi Tong

Secretary in General, Chinese National Committee for Remote Sensing Member of Chinese Academy of Sciences 